\title{
Audit of Budget Programs in European Union Countries
}

\author{
Inna V. Hnydiuk ${ }^{1}$, Ganna V. Datsenko 2,* , Irina H. Krupelnytska², Olena M. Kudyrko², \\ Olena O. Prutska ${ }^{1}$
}

\footnotetext{
${ }^{1}$ Department of Finance, Vinnytsia Institute of Trade and Economics, Kyiv National University of Trade and Economics, 21050 , Vinnytsia, Ukraine

${ }^{2}$ Department of Accounting and Taxation, Vinnytsia Institute of Trade and Economics, Kyiv National University of Trade and Economics, 21050, Vinnytsia, Ukraine
}

Received April 16, 2021; Revised July 19, 2021; Accepted August 5, 2021

\section{Cite This Paper in the following Citation Styles}

(a): [1] Inna V. Hnydiuk, Ganna V. Datsenko, Irina H. Krupelnytska, Olena M. Kudyrko, Olena O. Prutska, "Audit of budget programs in European Union countries," Universal Journal of Accounting and Finance, Vol. 9, No. 4, pp. 841 851, 2021. DOI: 10.13189/ujaf.2021.090430.

(b): Inna V. Hnydiuk, Ganna V. Datsenko, Irina H. Krupelnytska, Olena M. Kudyrko, Olena O. Prutska (2021). Audit of budget programs in European Union countries. Universal Journal of Accounting and Finance, 9(4), 841 - 851. DOI: 10.13189/ujaf.2021.090430.

Copyright $(2021$ by authors, all rights reserved. Authors agree that this article remains permanently open access under the terms of the Creative Commons Attribution License 4.0 International License

\begin{abstract}
Audit of budget programs in EU countries requires a detailed study of the audit procedure in order to minimize possible deviations and errors in the implementation of programs. The principal result of the audit of budget programs' indicators financed from EU funds is to verify the cost-effectiveness, efficiency and effectiveness of the use of budget resources. The purpose of the academic paper is to study the results of the audit of budget programs in EU countries in order to identify the causes and factors that influenced the violations and errors in the use of budget funds. The research methods are as follows: system and logical analysis; information synthesis method; systematization and generalization; comparison method; statistical analysis. Study contributes relevant information and processed data regarding to internal and external audit standards and mechanisms to improving their efficiency. Limitations of the study are possible unknown violations of the budget programs that result in inaccurate data analysis. Results. Conducting audit of the budget programs in the EU in accordance with international auditing standards complies with the generally accepted procedure for audit of using budget funds by beneficiaries. In 2019, as a result of the audit of budget programs by European Commission, it was found that 51 out of 130 transactions ( $39 \%$ ) contained violations and errors. A significant number of errors have been found in programs that direct budget funds to research and innovation. It has been revealed that most of the errors were found in the budget program Horizon 2020, in
\end{abstract}

connection with which the European Court of Auditors calls in question the eligibility of all costs declared by the beneficiary for the audit period. The main errors in reporting in other budget programs were reimbursements of travel expenses not related to the implemented EU budget program; the erroneous exchange rate used in the programs was not that provided by the rules of the program. The level of error in conducting audit of budget programs in 2019 has been $4.0 \%$, which is a significant reserve for improving the efficiency and effectiveness of the audit.

Keywords Beneficiary, Cost, Auditor, Expenditure, Transaction

\section{Introduction}

In the context of the world economy, globalization of the society, acceleration of transformation processes, budget programs play an important role in supporting social-economic transformations in many countries. Budget programs are a specific tool that affects the state of integration processes in the world economy, ensure the sustainable development of national economies of European Union (EU) member states and the implementation of projects that governments are unable to finance independently [1]. The formation of an effective system for managing budget funds as the basis for the development of all areas of the state policy 
implementation requires relevant and operational control, which would guarantee openness, transparency and accountability of state bodies to the society. The audit of budget programs conjoins a combined studying the factors of inefficient spending of budget funds and provides justification and development of appropriate recommendations and proposals for both the objects of control, within the functioning of which control measures have been performed, and its subjects [2].

With the integration of countries into international economic relations, the entities implementing budget programs are faced with the goal of providing reliable and objective information on the use of budget funds to the relevant Supreme Audit Institutions. In modern conditions, the problem of the reliability of the information presented in the reporting is especially acute, and the responsibility for the timely identification of errors in the reporting documentation is assigned to audit and control [3]. Audit of budget programs analyzes the quality of managing financial resources in terms of three components: efficiency, effectiveness and efficiency. The principal audit of EU co-financed budget programs is carried out by the external and internal auditors - European Court of Auditors and Internal Audit Service, in accordance with international auditing standards; however, some member states carry out audits on the basis of national legislation $[4 ; 5]$. The need to modernize the audit system of budget programs is caused by the intensification of interstate cooperation of EU member states and the intensification of their financial, economic and political ties (IOM, 2020). The importance of the practical use of the research results lies in the further adoption of measures in order to eliminate errors in the reporting documentation during the implementation of budget programs that will reflect the effectiveness of the use of EU budget funds by beneficiaries.

The purpose of the research is to study the results of the audit of budget programs in EU countries in order to identify the causes and factors that have influenced the violations and errors in the use of budget funds.

The research objectives of the academic paper are as follows:

1. To analyze the multiannual financial development programs of EU for the periods 2014-2020 and 2021-2027.

2. To identify budget programs with EU co-financing and investigate identified violations and errors based on the results of the audit of budget programs.

3. To investigate the principal EU audit organizations and the standards that guide EU countries in conducting audit of budget programs.

4. To develop a mechanism to enhance an efficiency of audit process.

\section{Literature Review}

The INTOSAI standards are the international standards for Supreme Audit Institutions which are external services and carry out external audit $[6,7 ; 8]$. Among the factors influencing the development of international auditing standards, K. Anerud [9] pays special attention to the internal control and reliability of the financial statements provided by the beneficiary. Enhanced internal control is considered as a factor influencing the emergence and development of international auditing standards in the public sector, forasmuch as they provide confidence towards the government regarding the verification of beneficiaries for budget expenditures in the implementation of budget programs [10].

International standards create a control environment, in which governments operate in such a way that the standards provide a mechanism by which reasonable assurance can be obtained that assets are protected, financial transactions are ethical, and financial reporting is reliable [11]. The reliability of the reporting provided by the beneficiaries is an important factor; it is an essential requirement of International Standards of Supreme Audit Institutions, forasmuch as it is necessary to comply with international standards in order to ensure quality audit work [12].

Considering that public administration aims to improve the efficiency of public expenditures [13; 14], the audit procedure for budget programs faces increased audit requirements. According to conducted investigations, the basic factor contributing to efficiency is an audit focused on analyzing and minimizing risks in order to achieve the goals and objectives of the public sector [15]. An important role in enhancing the accountability of the government and the public sector is played by the Supreme Audit Institutions, which conduct audit of budget programs by checking them and reporting on the use of budget funds by beneficiaries for the implementation of the budget program [16]. The current legislation of the Supreme Audit Institutions of EU member states has a significant impact on the audit of budget programs $[16 ; 17 ; 18]$, forasmuch as it concerns the scope of parliamentary powers of accountability and the independence, oversight, and authority of the Supreme Audit Institutions in conducting audit of budget programs.

The need to improve the system of supervision over the audit of budget programs arose due to the heterogeneity of public oversight of audits between the member states [19] With this end in view, EU aims to harmonize the audit supervision system of budgetary programs, trying to improve the quality of audits in its jurisdiction. For this purpose, Directive 2006 [20] was issued, which was amended in 2014 by Directive 2014 [21]. These directives aim to harmonize the requirements of statutory audit as well as the audit of budget programs. They recognize that the function of state auditors, which is conducive to the public good, determines the level of public confidence in the state, enterprises, institutions and organizations and depends on the quality of work performed by state auditors [22]. 


\section{Materials and Methods}

The implementation of the purpose of the present investigation provides the involvement of the following research methods, namely:

- analysis of the legal framework of EU countries and national and European audit organizations in order to study the features of the current methodology and practice of auditing budget programs;

- systematic and logical analysis, information synthesis method in order to study the national auditing bodies and standards in EU countries related to the audit of budget programs;

- systematization, generalization in order to study statistical data on the financing of budget programs from EU funds and the results of the audit of budget programs in EU countries.

The method of generalization of the modern regulatory practice of auditing budget programs in EU has been applied in order to determine particular signs of auditing budget programs. The use of the comparison method has made it possible to distinguish between national and international auditing standards for budget programs applied in EU member states. Based on statistical analysis, a model has been built to reflect the relationship between the number of errors identified by auditors and the expenditures of EU countries on budget programs. In the study of B.G. Osma, A. Gisberta and E. de las H. Cristóbal [23] it has been emphasized that despite the existence of relevant EU Directives, it is necessary to amend and implement European auditing standards in order to truly harmonize audit supervisory procedures in Europe for the effective functioning of the state by improving the integrity and efficiency of financial reporting in budget programs.

External audit of budget programs is conducted by the Supreme Audit Institution, through its structures and in accordance with its competence, forasmuch as this institution plays an important role in identifying violations [24]. Audit of budget programs is carried out at the end of the project or according to the schedule stipulated by the investor of financial resources [25], in accordance with Article 127 (1) of Regulation (EU) No. 1303/2013 in order to verify the effective functioning of management and control systems [26]. Also, various types of audits can be applied for budget programs of centralized directions of the Executive Agency, depending on the type of direction and the size of the grant (if applicable, audit type I for grants exceeding 60000 EUR and less than 750000 EUR; audit type II for grants of 750000 EUR or more [27]. Thus, the problem of auditing budget programs is widely reflected in scientific publications in the form of theoretical researches and practical investigations. Along with this, an in-depth analysis of the problems outlined in the scientific article makes it possible to conclude that the audit of budget programs in EU countries and its features in the context of in-depth integration of national economies into the structure of the pan-European social-economic space is insufficiently studied today by scientists.

\section{Results and Discussion}

Forasmuch as EU budget is mainly investment-based, it is adopted on a long-term basis in order to ensure stability and efficiency in achieving results. The Multiannual Financial Framework is adopted for a period of at least five years (usually seven years) and sets maximum limits on the annual amounts that EU can spend on different categories of expenditure over a given period. The lion's share of EU budget (about 75\%) is spent on regional development, natural resources and the fight against climate change; however, $6 \%$ of EU budget expenditures are used for administrative costs (Figure 1).

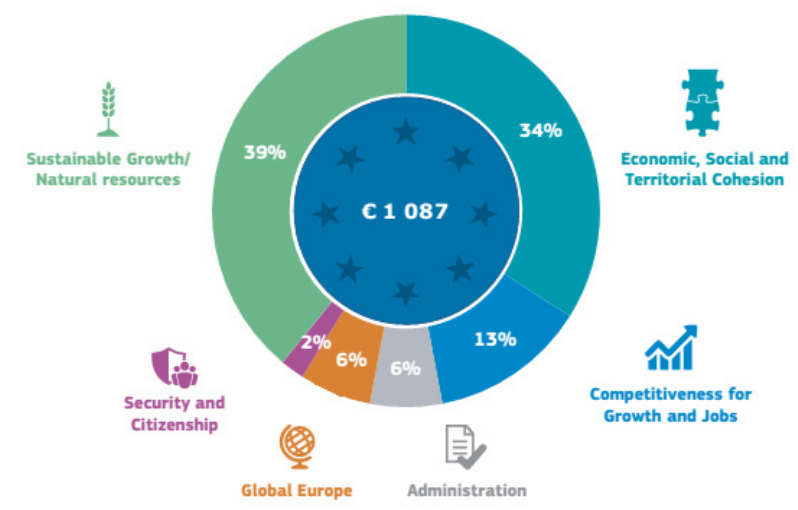

Source Compiled by the authors based on official data of European Commission [28].

Figure 1. EU Multiannual Financial Framework for 2014-2020 (billion EUR)

Long-term programs are reviewed on the basis of analysis of cost-effectiveness, efficiency and effectiveness of the use of budget resources, taking into account the results of audits of individual programs. If compare the long-term programs for 2014-2020 and 2021-2027, European Commission has proposed to allocate $30 \%$ less than the previous EU budget for the agricultural sector, and the main EU expenditures largely replace national expenditures on regional development and EU cohesion policy. The projected EU Multiannual Financial Framework (Figure 2) will run until 2027. Along with this, European Commission, based on a study of the previous Program and the challenges facing EU, increases funding for research, youth development, climate change, migration and borders, security and external influences. These directions are key ones in order to help Europe remain a world leader in a sustainable and environmentally friendly future and contribute to global security through development assistance and humanitarian assistance [28]. 


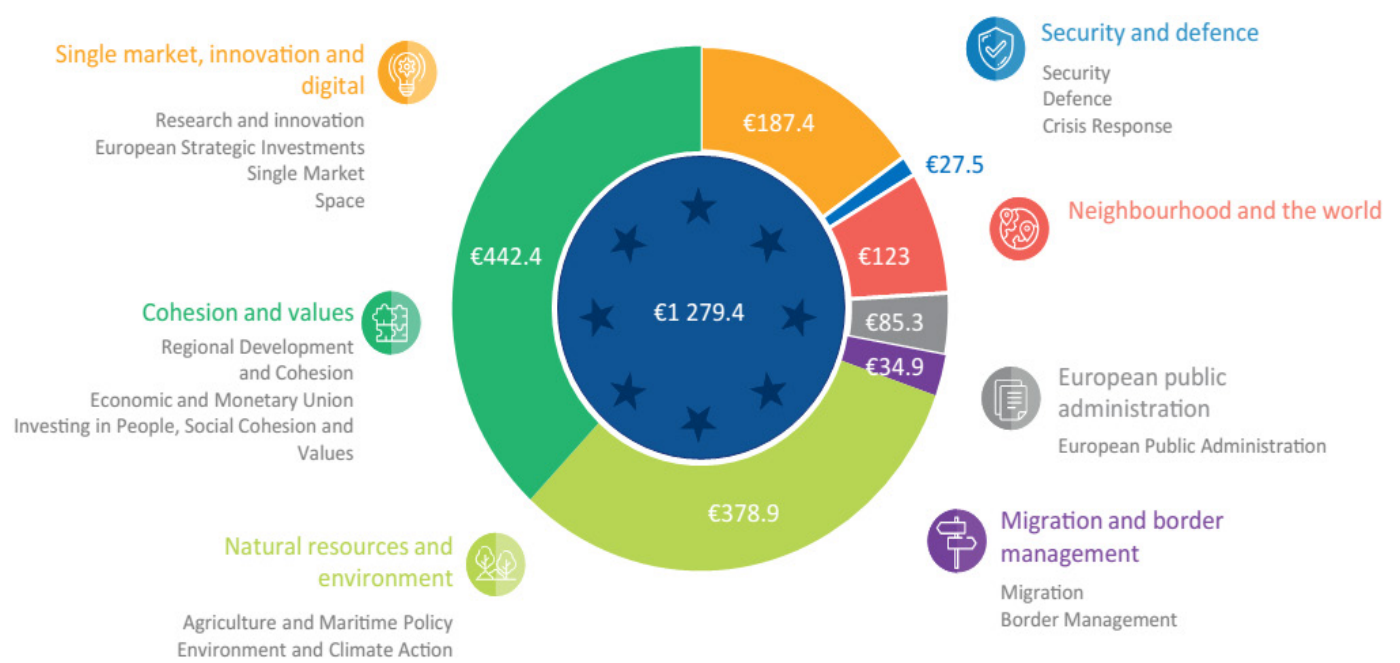

Source Compiled by the authors based on official data of European Commission [28]

Figure 2. EU Multiannual Financial Framework for 2021-2027 (billion EUR)

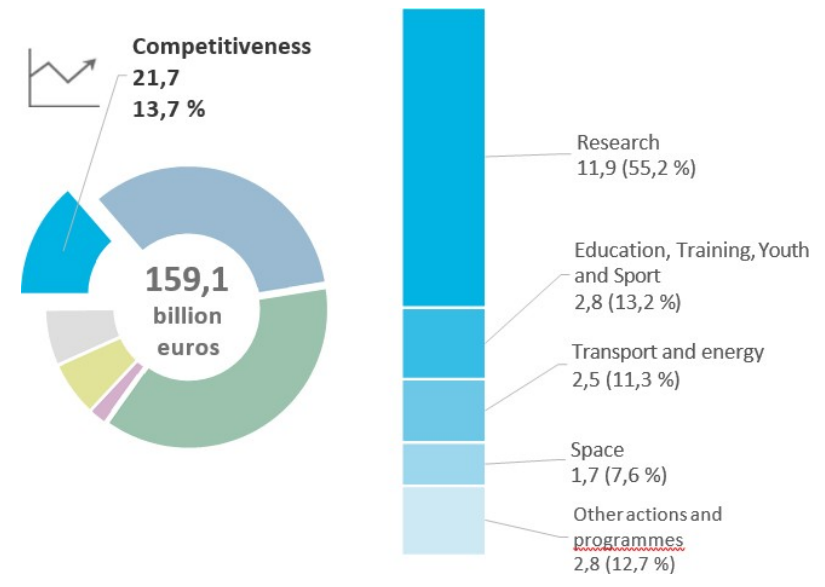

Source Compiled by the authors based on official data of European Court of Auditors [32].

Figure 3. Investment in budget programs of the sector "Competitiveness and increase of workplaces" in 2019 (billion EUR)

Programs funded directly by European Commission and programs funded by national bodies require in-depth expertise by auditors. After all, audit is an integral part of verifying the cost-effectiveness, efficiency and effectiveness of the use of budgetary resources. EU countries conduct audit of budget programs on the basis of national or INTOSAI (International Organization of Supreme Audit Institutions) by the relevant national audit body (Annex A). Most EU countries have switched to INTOSAI auditing standards; they are harmonized with SAI and national auditing standards $[6 ; 29]$. Budget programs play an important role in stimulating growth and creation of workplaces in EU. Such programs, as Horizon for research and innovation and Erasmus+ [26] for education, training, youth and sport constitute a major part of the expenditures. Other programs account for a smaller share of budget expenditures, namely "Galileo" (EU Global Navigation Satellite System), "Connecting Europe Facility" (CEF) and others [30; 31]. EU has amended many of its funding programs for 2014-2020. In 2019, the amount of 159,1 billion EUR was allocated from EU budget; more than $55 \%$ of the budget were directed to research programs, more than $13 \%$ of the budget were invested in education and training, sports and youth development programs, and more $11 \%$ of the funds were directed to the transport and energy sectors (Figure 3) [32; 33].

In 2019, EU budget expenditures in the amount of 2.17 billion EUR were the subject to an audit of budget programs, forasmuch as most budget resources were under the direct management of European Commission; they were provided in the form of grants to public or private beneficiaries who participated in budget programs [34; $35]$. Research and innovation programs accounted for $55.2 \%$ of EU budget expenditures audited in 2019. In 2019, 51 $(39 \%)$ of the 130 audited financial transactions in the budget programs contained errors, and the error rate was estimated at $4.0 \%$. In 2017 , this indicator was $4.2 \%$, in $2018-2.0 \%$. The calculation of the margin of error is based on a representative sample, where the European Court of Auditors [36] is at $95 \%$ confident that the estimated level of error in transactions of budget programs is from $1.5 \%$ to $6.4 \%$ (lower and upper error limits, respectively) (Table 1).

Table 1. Results of the audit of transactions in the sector "Competitiveness and increase of workplaces"

\begin{tabular}{|c|c|c|}
\hline & 2019 & 2018 \\
\hline \multicolumn{3}{|c|}{ Size and structure of the sample } \\
\hline Total transactions: & 130 & 130 \\
\hline \multicolumn{3}{|c|}{ Estimated impact of quantifiable errors } \\
\hline Estimated level of error & $4.0 \%$ & $2.0 \%$ \\
\hline Upper Error Limit (UEL) & $6.4 \%$ & $\mathrm{n} / \mathrm{a}$ \\
\hline Lower Error Limit (LEL) & $1.5 \%$ & $\mathrm{n} / \mathrm{a}$ \\
\hline
\end{tabular}

Source Compiled by the authors based on official data of European Court of Auditors [32].

The main reasons for these errors, as in previous years, 
are that the beneficiaries declare ineligible costs, which are neither detected nor corrected prior European Commission reimburses them $[37 ; 38]$. The auditors have revealed that most of the errors were related to ineligible costs (for instance, travel and equipment costs not related to the budget program), staff costs not directly incurred for the implementation of the budget program, and large costs for research infrastructure, erroneously declared by the beneficiaries [39; 40]. In 24 of Horizon 80 research and innovation transactions, inappropriate expenditures errors were found in the sample, which is $78 \%$ of estimated error rate for this sector "Competitiveness and increase of workplaces" in 2019. According to the results of European Court of Auditors [32], it has been found that research costs still contain significant errors, as a result of the calculations of European Commission, the level of errors of Horizon [41] in 2019 remains above 2\% of the materiality threshold.

Regarding other budget programs, European Court of Auditors [30] has revealed errors in 4 out of 50 transactions in the sample, where the errors mainly concerned Erasmus + [26] and CEF, namely: errors were caused by employees who used the wrong unit rate and declared ineligible costs; two violations were identified in procurement procedures and an inadmissible subcontractor (CEF). Staff costs continue to be a major source of error, especially in research expenditures. The rules for declaring staff costs in the Horizon (2020) budget program are complex; despite amendments to simplify the procedure, their calculation remains a major source of error in cost statements. 24 transactions were subject to quantitative errors in the sample of research transactions, and thereof 23 concerned the misapplication of the personnel cost methodology, where in almost all cases the hourly (or monthly) rate was miscalculated (Figure 4).

Most of the identified errors (17 out of 28 ) involved financing of private beneficiaries, although transactions accounted for only $42(32 \%)$ of the 130 transactions in the sample. Small and medium enterprises in the sample comprised $12 \%$, which accounted for $21 \%$ of quantitative errors. According to the specified results, this category of companies is more prone to errors than other beneficiaries, which is also confirmed by the audits of European Commission and the annual reports of European Court of Auditors [32]. Errors have been identified in four Horizon [41] projects; consequently, European Court of Auditors calls in question the eligibility of all costs declared by the beneficiary for the audit period. In two cases, the beneficiary was a $100 \%$ subsidiary of another company that paid the salary, as well as all other costs, where all employees involved in the program were employed by either the parent company or another subsidiary [42;43]. In contrast to the Horizon rules, which stipulate that the beneficiary should bear the costs and record them in the beneficiary's accounting system, this requirement has not been met and European Court of Auditors considers all costs declared by the beneficiary during the audited period to be ineligible. In both cases, the beneficiaries were insufficiently aware of the Horizon rules.

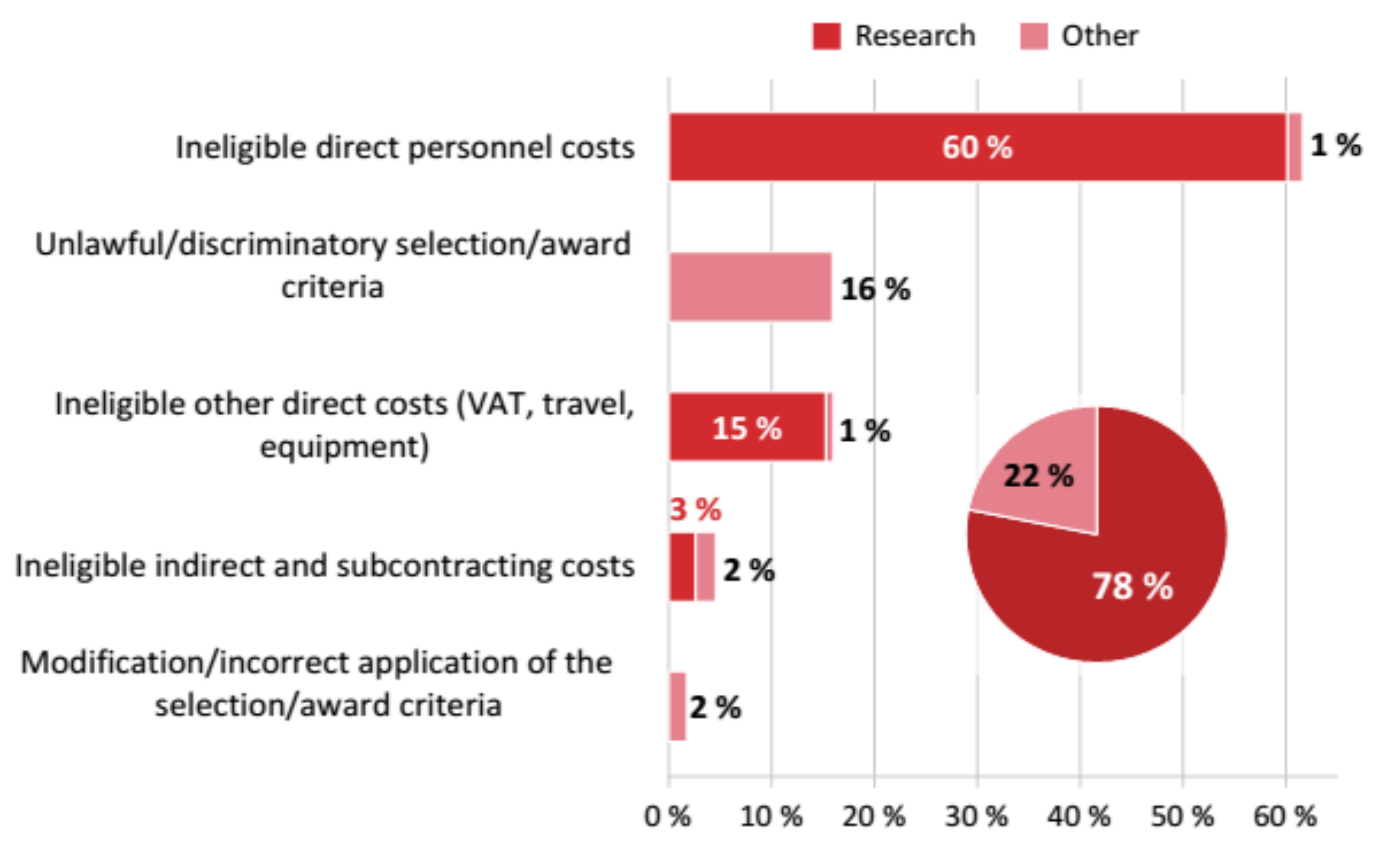

Source Compiled by the authors based on official data of European Court of Auditors [32].

Figure 4. Types of errors in budget programs identified during the audit in 2019. 
As in previous years, European Court of Auditors has revealed errors in other direct costs related to research expenditures, which included, in particular, reimbursement of costs not related to the implemented EU budget program. In 22 of the Court's audited budget programs, the auditors revealed that the budget programs were conducted in currencies other than euro; it has been also found that the exchange rate used in ten of these programs was not as required by the rules.

The financial impact of such errors is not significant in itself; however, their frequency demonstrates a lack of awareness of the rules in some EU countries. European Commission applied corrective measures that directly related to four of the 130 considered financial transactions in budget programs, where without these audit measures, the estimated margin of error would have been $0,1 \%$ higher. At the same time, sufficient information was available to prevent or detect and correct eight financial transactions in budget programs when auditors identified and quantified errors. If this information was used to correct errors, the overall projected level of budget expenditure error for "Competitiveness and increase of workplaces" would be $0.3 \%$ lower and, therefore, below the materiality threshold.

Horizon [41], on the other hand, has simpler rules for conducting financial transactions, according to which beneficiaries can declare capitalized and operating costs for research infrastructure. If they meet certain conditions, they receive a positive preliminary assessment of their costing methodology from European Commission. However, the 2019 audit has revealed that the preliminary assessment had little impact on error prevention. For Horizon, the audits were carried out by both European Commission and the external contracted auditors. In some documents, conflicting approaches to sampling and weaknesses in audit documentation and reporting, as well as in audit procedures, have been identified. A methodological weakness has been found in the calculation of the error rate: although previous audits rarely achieve their goal of maximum coverage of accepted costs, the error rate is systematically calculated on the basis of all the costs incurred instead of the amount actually checked, which leads to an underestimation of the error rate.
Regarding the audit of the Erasmus+ program [26], Education, Audiovisual and Culture Executive Agency (EACEA) has expressed warning about the effectiveness of its internal control over grant management. In addition, audits of Erasmus + projects have shown that some national rules have not been fully aligned with the principles applied in EU, in particular as regards the maximum amount to be paid and the funding mechanisms. After analyzing the report of European Commission on the results of the activities of 50 research and innovation budget programs, in accordance with the audit reports on the implementation of these programs, most of them achieved the expected results. However, in some cases, the audit report on progress only partially met the agreed objectives or the declared budget expenditures were disproportionate to the progress achieved. Herewith, in some cases, the budget costs of the program were not used as intended [30].

Table 2 reflects the distribution of the sample of the number of audit transactions and errors found in EU member states. The largest number of audits for the period 2014-2020 was conducted in Poland - 46, Spain - 24, Italy - 19, Portugal -18 , Germany - 17 ; however, no data are available for such countries, as: Slovakia, Bulgaria, Belgium, Finland, the Netherlands, Slovenia, Austria, Denmark, Ireland, Luxembourg. The largest number of errors were found in such countries, as: Poland (7 errors), Portugal (7 errors), Spain (4 errors), Germany (3 errors); however, no errors were found in France, Hungary, the Czech Republic, Estonia, Croatia, Lithuania, Latvia and Malta.

Table 3 reflects the simulation results, which make it possible to show the statistical relationship between the number of errors identified by auditors and the cost of EU countries on budget programs:

Errors in budget programs $=(-0.24)+3.88 *$ Quantified errors $+4942.73 *$ EUcontribution. (1)

Thus, errors in budget programs depend on the costs of EU countries and the efficiency of the use of funds by beneficiaries. The parameters of the model are statistically significant, as indicated by t Stat in the range of 4.04 and 8.64 and the value of P-value in the amount of 0.001 and 0.0000002 . 
Table 2. Information on audits by EU bodies in the Member States

\begin{tabular}{|c|c|c|c|}
\hline Member State & EU contribution (million euros) & Audited transactions 2014-2020 & Quantified errors \\
\hline Poland & 8696 & 46 & 7 \\
\hline Italy & 3426 & 19 & 2 \\
\hline Germany & 3202 & 17 & 3 \\
\hline France & 3117 & 16 & 0 \\
\hline Portugal & 2710 & 18 & 7 \\
\hline Hungary & 2551 & 7 & 0 \\
\hline The Czech Republic & 2046 & 9 & 0 \\
\hline Romania & 1978 & 13 & 2 \\
\hline Spain & 1934 & 24 & 4 \\
\hline Greece & 1388 & 10 & 1 \\
\hline The United Kingdom & 888 & 10 & 1 \\
\hline Estonia & 648 & 7 & 0 \\
\hline Lithuania & 529 & 1 & 0 \\
\hline Croatia & 494 & 1 & 0 \\
\hline Sweden & 398 & 8 & 1 \\
\hline Latvia & 262 & 10 & 0 \\
\hline Cyprus & 137 & 8 & 1 \\
\hline Malta & 88 & 7 & 0 \\
\hline Slovakia & 1236 & - & - \\
\hline Bulgaria & 680 & - & - \\
\hline Belgium & 452 & - & - \\
\hline Finland & 423 & - & - \\
\hline The Netherlands & 316 & - & - \\
\hline Slovenia & 256 & - & - \\
\hline Austria & 214 & - & - \\
\hline Denmark & 71 & - & - \\
\hline Ireland & 68 & - & - \\
\hline Luxembourg & 12 & - & - \\
\hline
\end{tabular}

Source Compiled by the authors based on official data of European Court of Auditors (2020).

Table 3. Simulation results

\begin{tabular}{|c|c|c|c|c|c|c|c|c|}
\hline \multicolumn{9}{|c|}{ Regression Statistics } \\
\hline Multiple R & \multicolumn{8}{|c|}{0.56} \\
\hline R Square & \multicolumn{8}{|c|}{0.31} \\
\hline Adjusted R Square & \multicolumn{8}{|c|}{0.27} \\
\hline Standard Error & \multicolumn{8}{|c|}{1.95} \\
\hline Observations & \multicolumn{8}{|c|}{18} \\
\hline \multicolumn{9}{|c|}{ ANOVA } \\
\hline & $\mathrm{df}$ & SS & \multicolumn{2}{|c|}{ MS } & \multicolumn{2}{|c|}{$\mathrm{F}$} & \multicolumn{2}{|c|}{ Significance F } \\
\hline Regression & 1 & 27.53 & \multicolumn{2}{|c|}{27.53} & \multicolumn{2}{|c|}{7.25} & \multicolumn{2}{|c|}{0.016} \\
\hline Residual & 16 & 60.74 & \multicolumn{2}{|c|}{3.80} & & & & \\
\hline \multirow[t]{2}{*}{ Total } & 17 & 88.28 & & & & & & \\
\hline & Coefficients & $\begin{array}{l}\text { Standard } \\
\text { Error }\end{array}$ & $\mathrm{t}$ Stat & P-value & $\begin{array}{l}\text { Lower } \\
95 \%\end{array}$ & $\begin{array}{l}\text { Upper } \\
95 \% \\
\end{array}$ & $\begin{array}{l}\text { Lower } \\
95.0 \%\end{array}$ & Upper $95.0 \%$ \\
\hline Intercept & -0.24 & 0.09 & -2.69 & 0.00 & -0.43 & -0.05 & -0.43 & -0.05 \\
\hline Quantified errors & 3.88 & 0.96 & 4.04 & 0.001 & 1.84 & 5.91 & 1.84 & 5.91 \\
\hline EU contribution & 4942.73 & 572.19 & 8.64 & 0.000 & 3729.74 & 6155.72 & 3729.74 & 6155.72 \\
\hline
\end{tabular}

Source Compiled by the authors based on official data of European Court of Auditors (2020). 
The value of the coefficient of determination indicates that the model explains by $27 \%$ the relationship between the costs of EU countries on budget programs and independent variables. This indicates that there are still many other factors influencing the effectiveness of the implementation of budget programs that are not included in the regression model. In particular, there are more errors in auditing among countries that do not apply ISSAI [29] to conduct audit of budget programs, or use national standards that are harmonized with ISSAI. Such countries include Poland (it applies national auditing standards), Portugal (it applies ISSAI on a voluntary basis), Romania (National regulations are applied that comply with ISSAI).

The budgeting system in EU is improved and well-defined; it reflects various aspects of assessing the effectiveness and efficiency of activities, including the strengths and weaknesses that appear at the national level of individual EU countries. EU budgetary practice includes numerous effective and innovative aspects that set an example for national governments on performance-oriented budget reforms. One of the effective components of the budgeting system in EU is the audit of budget programs [44]. State support occupies a central place in solving EU problems, while open budgeting, confidence in the allocation of funds and their use can increase government policy support from citizens living in countries that are beneficiaries of the EU budget [45]. EU budget programs are flexible; they are constantly changing under the influence of global challenges and taking into account the needs of beneficiary countries, while they are becoming increasingly subject to control by special audit bodies of EU member states and European Commission.

M. Mocanu and O. Iancu Ionescu [22] emphasize the importance of statutory audit in order to protect the interests of interested parties and increase confidence in capital markets at the level of European Union. Efforts to harmonize the audit supervisory system and promote transparency in the audit market based on Directive 2006/43/EC [20] and the new Directive 2014/56/EU [21] promote high quality auditing. At the same time, the results of the conducted audit of budget programs indicate the presence of violations in EU member states regarding the use of budget programs, as well as a significant amount of error in conducting audits $(2019-4.0 \%, 2018$ $-2.0 \%, 2017-4.2 \%)$. This size of the error indicates the presence of unused reserves in the audit of budget programs, the identification and use of which may have a positive effect.

Most decisions within EU continue to be made at member states' level. However, decisions are taken centrally at EU level in an increasing number of issues, including various economic, foreign and social policies. In this aspect, public policy is directed to those areas of actions, in which individual governments deliberately pursue (or avoid) their own policies, which are not always effective [46; 47]. The conducted research confirms this approach, forasmuch as the application of own national standards for the audit of budget programs is not always justified. This is evidenced by a comparison of the number of violations identified by auditors regarding the use of EU budget programs by beneficiary countries and their use of ISSAI [29] for the audit. Along with this, it has been proved that violations in the application of funds in the implementation of budget programs depend on the number of expenditures of EU member states and the efficiency of the use of funds by beneficiaries.

L. Feleagă, N. Feleagă and M. Dumitrașcu [11] prove that the existence of clear, transparent, understandable audit procedures is also preventive in nature, and their application has a positive impact on the results of the audit and the establishment of a balance between the rationality and effectiveness of procedures. The results of the research suggest that the number of errors in the use of budget funds is influenced by the level of awareness of beneficiaries about the current funding rules and the procedure for auditing budget expenditures [48; 49]. Most of the audit's results of the use of budget funds reveal errors in the reporting documentation during the implementation of the program by the beneficiary countries. Simplification of the rules for declaring staff costs and high expenditures for research infrastructure will also have a positive impact on the efficiency of the use of funds. For example, for the implementation of Horizon [33], the beneficiary should take appropriate measures in order to address the comments made during the audits on the consistency of the sample, documentation and reporting on the results of the budget program $[50,51]$. At the same time, one should take into account the conclusions of Internal Audit Service of European Commission on EACEA's internal control systems regarding the process of managing grants for the Erasmus + program [26] and monitoring of compliance with contractual obligations and reporting requirements for the use of budget funds in research and innovation projects.

\section{Conclusions}

A Improving the conceptual framework for the audit of budget programs can become a modern paradigm for maintaining globalization trends and mechanisms for the integration of national economies of EU into the world community. Increasing the capabilities and widespread use of innovative and research approaches to regulating the audit of budget programs at the interstate level of allocation of EU financial resources can become the basis of a pan-European financial strategy for future periods. As a result, the use of best practices and regulatory framework of the audit, agreed by the relevant financial 
supervisors, becomes a topic of great interest both for the institutions themselves and for the public sector as a whole in the distribution of financial resources between EU member states.

Despite the fact that European Commission regularly conducts audits of budget programs, the results of which are made public, openly discussed; however, it is almost impossible to completely avoid errors in the reporting documentation. Herewith, the level of these errors remains significant, which is an untapped reserve for both improving audit methodology and the efficiency of the use of budget programs at EU level. Implementation of transparent, accessible, understandable requirements for the proper use of budget funds by beneficiaries in the introducing budget programs will reduce the likelihood of distortion of reporting information. The application of uniform rules for conducting audit of budget programs based on international ISSAI standards will have a positive impact on the number of violations identified by auditors regarding the use of EU budget programs. Further investigations may be aimed at studying international standards for auditing budget programs in order to identify and systematize the best world practices that will help identify shortcomings in the implementation and introduction of the system for monitoring the effectiveness of budget programs.

\section{REFERENCES}

[1] E. M. Maksymov, M. W. Nelson, W. R. Kinney. Budgeting audit time: effects of audit step frame and verifiability, Behavioral Research in Accounting, Vol. 30, No. 1, 59-73, 2018.

[2] D. Z. Khudhair, F. K. A. Al-Zubaidi, A. A. Raji. The effect of board characteristics and audit committee characteristics on audit quality, Management Science Letters, Vol. 9, No. 2, 271-282, 2019.

[3] F. Amyar, N. N. Hidayah, A. Lowe, M. Woods. Investigating the backstage of audit engagements: the paradox of team diversity, Accounting, Auditing and Accountability Journal, Vol. 32, No. 2, 378-400, 2019.

[4] A. Tiron Tudor. Performance audit in public sector entities - a new challenge for Eastern European countries, Transylvanian Review of Administrative Sciences, Vol. 19, 126-141, 2007.

[5] N. R. A. M. Noor, N. Mansor. The mediating role of whistleblowing practice between types of audit and effectiveness of public sector audit, International Journal of Advanced Science and Technology, Vol. 28, No. 15, 140-147, 2019.

[6] INTOSAI, ISSAI 1: The Lima Declaration, 1977, Online available from https://www.issai.org/pronouncements/intosai-p-1-the-lima -declaration/.
[7] G. Drogalas, K. Petridis, N. E. Petridis, E. Zografidou. Valuation of the internal audit mechanisms in the decision support department of the local government organizations using mathematical programming, Annals of Operations Research, Vol. 294, No. 1-2, 267-280, 2020.

[8] S. White, S. Bailey, D. Asenova. Blurred lines: exploring internal auditor involvement in the local authority risk management function, Public Money and Management, Vol. 40, No. 2, 102-112, 2020.

[9] K. Anerud. Developing international auditing standards: cooperation between INTOSAI and the International Federation of Accountants, International Journal of Government Auditing, Vol. 31, No. 4, 20-24, 2004.

[10] S. D. Gherai, G. I. Tara, E. D. Matica. Perspectives in the application of the international standards of Supreme Audit Institutions, The Annals of the University of Oradea. Economic Sciences, Vol. 26, No. 1, 347-353, 2017.

[11] L. Feleagă, N. Feleagă, M. Dumitrașcu. Study on the Impact that the trust has on the auditors' professional judgment, Audit Financia, Vol. 9, 12-16, 2013.

[12] ISSAI 100, Fundamental Principles of Public-Sector Auditing, 2001, Online available from https://www.issai.org/wp-content/uploads/2019/08/ISSAI100-Fundamental-Principles-of-Public-Sector-Auditing.pd f.

[13] S. K. Aikins. An examination of government internal audits role in improving financial performance, Public Finance and Management, Vol. 11, No. 4, 306-337, 2011.

[14] M. Sterck, G. Bouckaert. International audit trends in the public sector, Internal Auditor, Vol. 63, No. 4, 49-53, 2006.

[15] P. Coetzee, D. Lubbe. Improving the efficiency and effectiveness of risk - based internal audit engagements, International Journal of Auditing, Vol. 18, No. 2, 115-125, 2014.

[16] C. Clark, M. De Martinis, M. Krambia-Kapardis. Audit quality attributes of European Union supreme audit institutions, European Business Review, Vol. 19, No. 1, 40-71, 2007.

[17] R. Kiraka, C. Clark, M. De Martinis. Public sector auditing, accountability and independence: a study of ASEAN countries, Asian Review of Accounting, Vol. 9, No. 2, 43-61, 2002.

[18] M. De Martinis, C. Clark. The accountability and independence of the auditors-general of Australia: a comparison of their enabling legislation, Australian Accounting Review, Vol. 13, No. 3, 26-35, 2003.

[19] S. J. Maijoor, A. Vanstraelen. Research opportunities in auditing in the EU. Revisited. Auditing, A Journal of Practice and Theory, Vol. 31, No. 1, 115-126, 2012.

[20] Directive 2006/43/EC of the European Parliament and of the Council of 17 May 2006 on statutory audits of annual accounts and consolidated accounts, amending Council Directives 78/660/ EEC and 83/349/EEC and repealing Council Directive 84/253/EEC, 2006, Online available from https://eur-lex.europa.eu/legal-content/EN/TXT/?uri=celex $\% 3$ A32006L0043. 
[21] Directive 2014/56/EU of the European Parliament and of the Council of 16 April 2014, amending Directive 2006/43/EC on statutory audits of annual accounts and consolidated accounts, 2014, Online available from https://eur-lex.europa.eu/legal-content/EN/TXT/?uri=celex $\% 3$ A32014L0056.

[22] M. Mocanu, O. Iancu Ionescu. Interrelation of capital markets in the context of increased audit oversight in the European Union - evidence on third-country auditors, Zagreb International Review of Economics \& Business, Vol. 23, No. 1, 71-80, 2020.

[23] B. G. Osma, A. Gisbert, E. de las H. Cristóbal. Public oversight systems for statutory auditors in the European Union, European Journal of Law and Economics, Vol. 44, 517-552, 2017.

[24] T. Schillemans, M. van Twist, M. van der Steen, I. de Jong. New development: breaking out or hanging on? Internal audit in government. Public Money and Management, Vol. 38, No. 7, 531-534, 2018.

[25] BDO Finland, Auditing of EU Projects and Subsidies, 2020, Online available from https://www.bdo.fi/en-gb/services/audit-assurance/projectaudits/auditing-of-eu-projects-and-subsidies.

[26] EU Funds, Manual of procedures for projects implementation cohesion policy 2014-2020 Malta, Guide to beneficiaries, 2014, Online available from https://eufunds.gov.mt/en/Operational\%20Programmes/Us eful\%20Links\%20and\%20Downloads/Documents/2014-2 020/Manual\%20of\%20Procedures\%202014-2020.pdf.

[27] Erasmus + , Programme guide, 2019, Online available from $\mathrm{https}$ ://ec.europa.eu/programmes/erasmus-plus/resources/p rogramme-guide_en.

[28] European Commission, EU budget at a glance, 2019, Online available from https://ec.europa.eu/info/sites/info/files/about the_europea n_commission/eu_budget/budget-brochure-a5-17-05_inter active.pdf.

[29] ISSAI, Introduction, 2017, Online available from http://www.ecosai.org.pk/03\%20Salient $\% 20$ Features $\% 20$ o f\%20ISSAIs.pdf.

[30] 30European Court of Auditors, Public audit in the European Union, The supreme audit institutions in the EU and its member states, Publications Office of the European Union, Luxembourg, 2019.

[31] A. A. Tkachenko. Criteria of depressed status of a region, Vestnik Moskovskogo Universiteta, Seriya 5: Geografiya, Vol. 4, 66-71, 1996.

[32] European Court of Auditors, Annual reports on the implementation of the EU budget for the 2019 financial year and on the activities funded by the 8th, 9th, 10th and 11th European Development Funds (EDFs), Publications Office of the European Union, Luxembourg, 2020.

[33] O. I. Vasylieva, S. V. Slukhai, S. K. Khadzhyradieva, A. A. Klochko, A. G. Pashkova. Ukrainian civil service: implementation of the public administration reform strategy in Ukraine, Journal of Advanced Research in Law and Economics, Vol. 11, No. 4, 1439-1445, 2020.
[34] O. S. Aleksandrova, V. V. Loiko, N. M. Vinnikova. Trade in the Decade Following the Collapse of the USSR, Visual Anthropology, Vol. 33, No. 2, 128-137, 2020.

[35] T. V. Yereskova, O. V. Mazuryk, O. S. Aleksandrova, H. V. Tymofieieva, V. N. Zavadskyi. Uncertainty as a regular feature of modern Ukrainian society, Teorija in Praksa, Vol. 57, No. 3, 928-946, 2020.

[36] European Court of Auditors, EU Audit in Brief. Introducing the 2018 Annual Reports of the European Court of Auditors, Publications Office of the European Union, Luxembourg, 2018.

[37] A. Tokarskiy, D. Topchiy. State construction supervision during repurposing project implementation in the urban areas, IOP Conference Series: Materials Science and Engineering, Vol. 698, No. 6, Article number: 066061, 2019.

[38] A. Tkachenko. The importance of the ILO in international processes the centenary of the international organization, Mezhdunarodnye Protsessy, Vol. 17, No. 3, 36-50, 2019.

[39] E. I. Efremova, E. A. Fedchenko, A. A. Kurashova, E. A. Shevereva, N. V. Bondarchuk, N. V. Lashchinskaya. Methods of assessing feasibility of involvement of the audit organization in the public procurement, Journal of Advanced Research in Law and Economics, Vol. 10, No. 8, 2327-2334, 2019.

[40] E. I. Efremova, A. A. Kurashova, I. S. Medina, E. A. Fedchenko, M. L. Vasyunina, E. I. Bakhtigozina. Organization and functioning of the internal control service in an outsourcing organization, Astra Salvensis, Vol. 1, 491-497, 2019.

[41] Horizon, How to Get Funding? 2020, Online available from https://ec.europa.eu/programmes/horizon2020/node/115.

[42] D. V., Topchiy, A. I. Shatrova. Formation of a basic management strategy for a construction organization in the implementation of projects of redevelopment of major urban areas, International Journal of Mechanical Engineering and Technology, Vol. 9, No. 4, 539-547, 2018.

[43] E. I. Bakhtigozina, E. Efremova, E. A. Shevereva, A. A. Kurashova, E. I. Nalbatova. Fraud in the organization and direction of control in order to prevent it, Espacios, Vol. 39, No. 39, 1-6, 2018.

[44] M. A. Islam, C. Deegan, R. Gray. Social compliance audits and multinational corporation supply chain: evidence from a study of the rituals of social audits, Accounting and Business Research, Vol. 48, No. 2, 190-224, 2018.

[45] L. M. Dellmuth, A. W. Chalmers. All spending is not equal: European Union public spending, policy feedback and citizens' support for the EU, European Journal of Political Research, Vol. 57, 3-23, 2018.

[46] R. R. Gamayuni. The effect of internal auditor competence and objectivity, and management support on effectiveness of internal audit function and financial reporting quality implications at local government, International Journal of Economic Policy in Emerging Economies, Vol. 11, No. 3, 248-261, 2018.

[47] C. Clark, M. De Martinis, R. Kiraka. Transformation of public sector auditing in southern African countries: comparing the independence and accountability of supreme 
audit institutions, South African Journal of Public Administration, Vol. 38, No. 2, 118-132, 2003.

[48] International Organization for Migration (IOM), World Migration Report 2020, International Organization for Migration, Geneva, 2020.

[49] S. Rahayu, S. Yudi, S. Rahayu. Internal auditors role indicators and their support of good governance, Cogent Business and Management, Vol. 7, No. 1, Article number: 1751020,2020
[50] R. Keng'ara, I. Makina. Effect of budgetary processes on organizational performance: a case of marine state agencies, Kenya, Universal Journal of Accounting and Finance, Vol. 8, No. 4, 115-130, 2020. DOI: 10.13189/ujaf.2020.080404

[51] C. P. A. Fortuna. Budgeting practices: its impact on the profitability of small and medium enterprises in Isabela, Universal Journal of Accounting and Finance, Vol. 9, No. 3, 336-346, 2021. DOI: 10.13189/ujaf.2021.090307 